\title{
Design and Implementation of Boost Voltage Doubler for Maximum Power Point Tracker Application Using STM32F1038CT
}

\author{
Laras Triefena $^{1 *}$, Leonardus H. Pratomo ${ }^{2}$, Slamet Riyadi ${ }^{3}$, F. Budi Setiawan ${ }^{4}$ \\ ${ }^{1,2,3,4}{ }^{2}$ Electrical Engineering Departement Soegijapranata Catholic University \\ Pawiyatan Luhur IV/1 St, Semarang 50234, Indonesia \\ *Corresponding Email: triefenalaras@gmail.com
}

Received 29 September 2020, Revised 30 October 2020, Accepted 28 November 2020

\begin{abstract}
Photovoltaic is an absolute device in the solar power plant system. A DC-DC converter with a maximum power point tracker (MPPT) algorithm is required to obtain the maximum power of photovoltaic. In general, solar power plant applications used a two-stage converter: the first stage is boosting DC-DC converter, and the second stage is the multilevel Inverter. Boost DC-DC converter is usually implemented singly, which causes many boost DC-DC converters to be implemented in a solar power plant application. The voltage doubler type boost DC-DC converter proposed in this paper is to simplify the circuit so that there is only one converter in a solar power plant application. This converter principle combines two conventional boost converters, which are integrated into one so that the power circuit and control circuit form become simpler. This proposal is verified through computation simulation and hardware design using the STM32F1038CT microcontroller for the final verification. The efficiency algorithm of the simulation is $99.7 \%$, and the hardware experimental is $85.65 \%$.
\end{abstract}

Keywords - MPPT, boost, voltage doubler, STM32F1038CT

Copyright @ 2020 JURNAL INFOTEL

All rights reserved.

\section{INTRODUCTION}

Nowadays, the usage of photovoltaic has increased in line with the increased long electrical energy. It is caused by increased human population and economic growth. Photovoltaic (PV) is a device of converting energy from sunlight to electrical energy. It is required in the application of the solar power plant. Sun rays' intensity affects the photovoltaic power output, which the sun rays depend on weather and climate where the photovoltaics are. To achieve maximum work of power output from photovoltaic is uses a system called maximum power point tracker (MPPT) [1],[2]. Some algorithms are often used to achieve MPPT, such as Ripple Correlation Control (RCC), fractional open voltage and fractional short circuit, perturbation and observation $(\mathrm{P} \& \mathrm{O})$, incremental conductance (IC), proportional-integral controller, fuzzy logic, and neural network. From many algorithms, P\&O is chosen since it is easier [3],[4].

However, photovoltaic produces the DC voltage output at a low range and cannot directly support AC or DC electrical appliances [5]. Therefore, this necessitates a two-stage converter [6]: the first stage is maximized with a converter based on algorithm MPPT in the boost DC-DC converter. The second is converted into AC using a 5-level inverter. Fig.1 is shown an example of a 5-level inverter commonly used in solar power plants application [7].

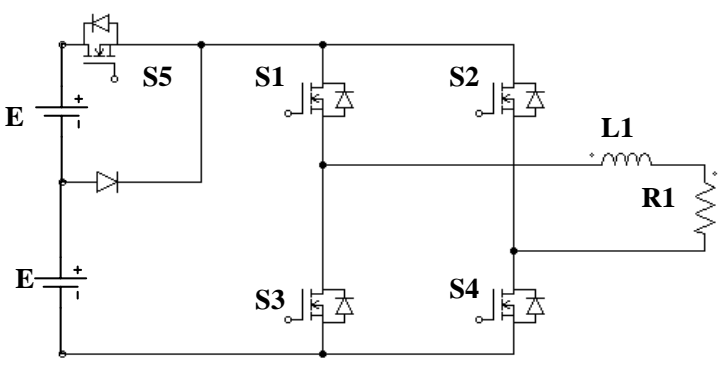

Fig.1. 5-Level Inverter

Photovoltaic primarily used a conventional boost converter to generate a high DC voltage [8]. However, conventional boost converter has many drawbacks, 
such as having a large size because of low-frequency operation and conduction losses because of high voltage stress on switch [9],[10]. That drawbacks make conventional boost converter to be not efficient [11],[12]. The system uses two conventional boosts DC-DC converter, which causes many boost DC-DC converters to be implemented in solar power plant application[13]-[15]. To realize an efficient step-up converter, the voltage doubler technique can be applied. It can reduce the rectifier diode's voltage stress; thus, the conduction losses are significantly reduced, and the converter efficiency can be improved [5]. The boost voltage doubler is suitable for operating both power grid or battery [16] and can achieve the high range voltage output using simple frequency control [17].

Boost Voltage Doubler proposed replacing two conventional boost DC-DC converters based on the MPPT algorithm with the P\&O method. Photovoltaic is used power source by implementing solar power plant application. To generate maximum power, a converter based on MPPT is used. Hardware implementation uses an STM32F1038CT microcontroller. As the first section of this research describes the operation mode of the boost voltage doubler. The second section describes the boost voltage doubler and its integration with MPPT. Algorithm programming will be presented in the third section. Simulation, implementation, and discussion will be presented in the fourth section.

\section{RESEARCH METHOD}

The solar power plant uses a two-stage converter, photovoltaic maximized using a converter based on algorithm MPPT into DC, then converted into AC as shown in Fig.2. As usual, a DC-DC converter is used to increase the low voltage from the solar panel. In order to increase efficiency.

The research method describes the working principle of boost voltage doubler, MPPT based on the $\mathrm{P} \& \mathrm{O}$ algorithm through flowchart program, and STM32F1038CT as a device to control boost voltage doubler using $\mathrm{P} \& \mathrm{O}$ algorithm method.

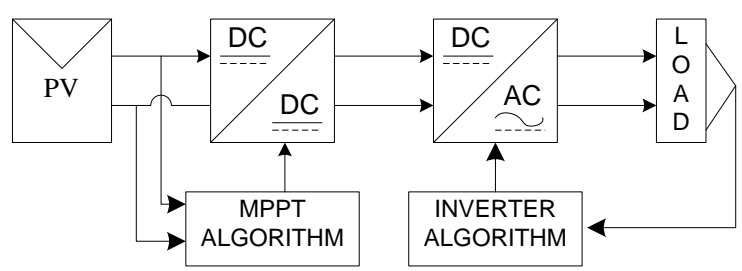

Fig.2. Two-Stage Converter

\section{A. Boost Voltage Doubler}

Voltage doubler can be used for step-up voltage applications because the output voltage is double the input voltage [18],[19]. Boost voltage doubler, in principle, is a combination of two boosts DC-DC converter as shown in Fig.3. The equivalent circuit of boost voltage doubler is consists of a resistor $(\mathrm{R})$ as a load, a source voltage $\left(\mathrm{V}_{\mathrm{PV}}\right)$, two switches ( $\mathrm{S} 1$ and $\mathrm{S} 2$ ), two inductors (LI and L2), and two capacitors (C1 and $\mathrm{C} 2$ ).

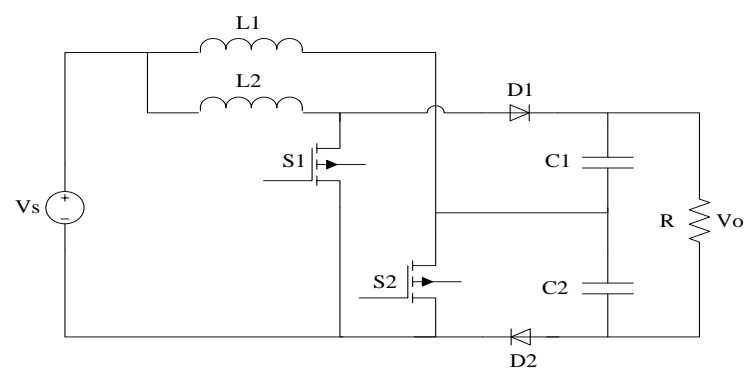

Fig.3. Topology Boost Voltage Doubler

Boost voltage doubler can be divided into four operation modes based on the switching cycle.

Operation Mode 1: Power switches S2 as shown in Fig.4(a) and S1 Fig.4(b) are set to ON state. Current flows from voltage source $\mathrm{V}_{\mathrm{PV}}$ and the energy stored in L1 and L2, respectively. The inductor voltage for L1 and L2 can be expressed as

$$
\begin{aligned}
& V_{L 1}=L \frac{d i_{L 1}}{d t}=V_{P V} \\
& V_{L 2}=L \frac{d i_{L 2}}{d t}=V_{P V}
\end{aligned}
$$

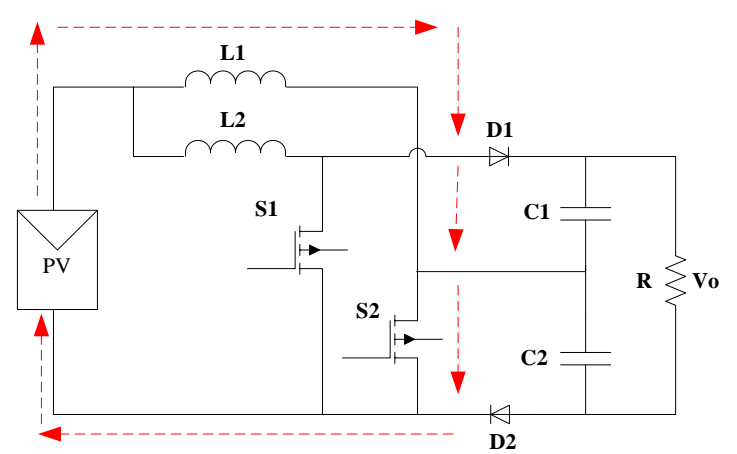

(a)

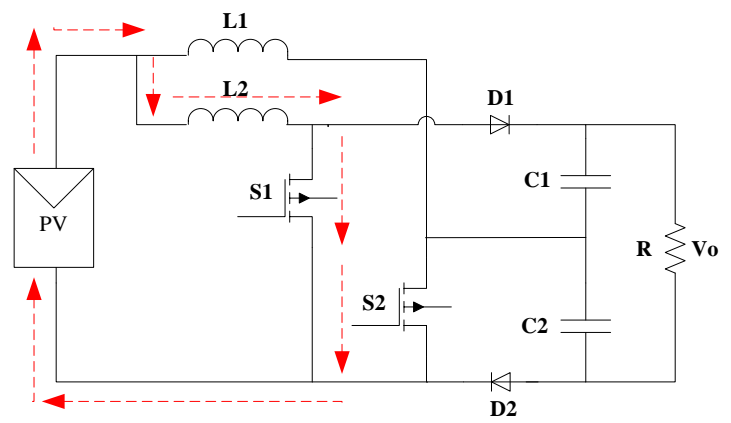

(b)

Fig.4. Mode Operation 1; (a) S2 ON, (b) S1 ON

Operation Mode 2: As shown in Fig.5, power switches S2 Fig.5(a) are set to ON state. So that, current flows from voltage source Vs to L1. 
Meanwhile, S1 Fig.5(b) is in the OFF state, so current flows voltage source Vs to L2 through D1 and R, then back to source voltage through $\mathrm{D} 2$. The inductor voltage for L1 and L2 can be express as

$$
\begin{aligned}
& V_{L 1}=L \frac{d i_{L 1}}{d t}=V_{P V} \\
& V_{L 2}=L \frac{d i_{L 2}}{d t}=V_{P V}-V_{C 1}
\end{aligned}
$$

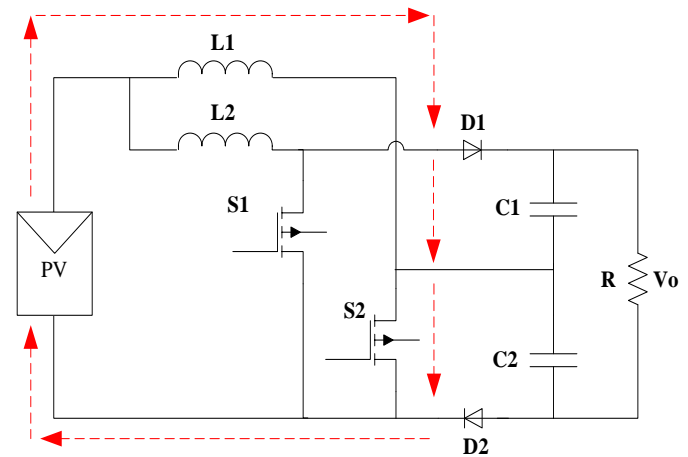

(a)

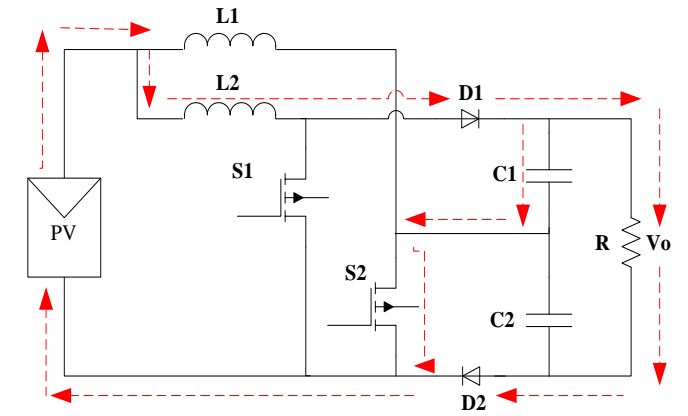

(b)

Fig.5. Mode Operation 2; (a) S2 ON, (b) S1 OFF

Operation Mode 3: Power switches S2 as shown in Fig.6(a) is set to OFF state. Meanwhile, an S Fig.6(b) is set to ON state. The inductor voltage for L1 and L2 can be expressed as

$$
\begin{aligned}
& V_{L 1}=L \frac{d i_{L 1}}{d t}=V_{P V}-V_{C 2} \\
& V_{L 2}=L \frac{d i_{L 2}}{d t}=V_{P V}
\end{aligned}
$$

Operation Mode 4: Power switches S2 as shown in Fig.7(a) and S1 Fig.7(b) are set to OFF state. Current flows from a voltage source (Vs) to load $\mathrm{R}$ through L1 and L2, then back to Vs through D1 and D2. The inductor voltage for L1 and L2 can be expressed as

$$
\begin{aligned}
& V_{L 1}=L \frac{d i_{L 1}}{d t}=V_{P V}-V_{C 2} \\
& V_{L 2}=L \frac{d i_{L 2}}{d t}=V_{P V}-V_{C 1}
\end{aligned}
$$

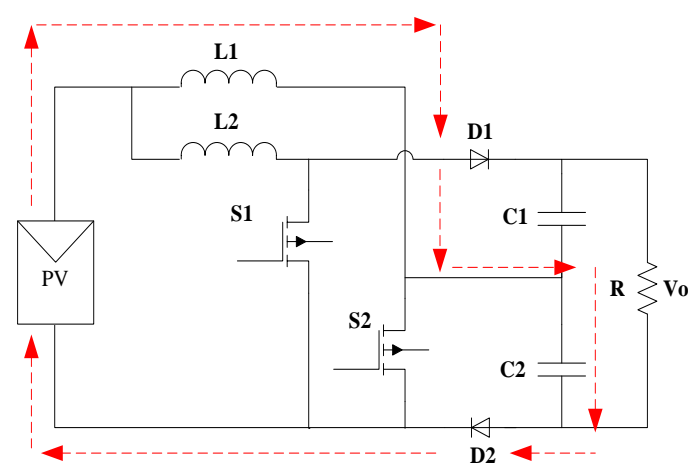

(a)

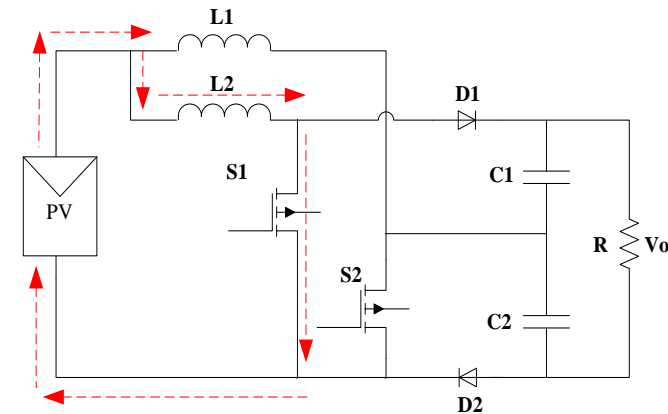

(b)

Fig.6. Mode Operation 3; (a) S2 OFF, (b) S1 ON

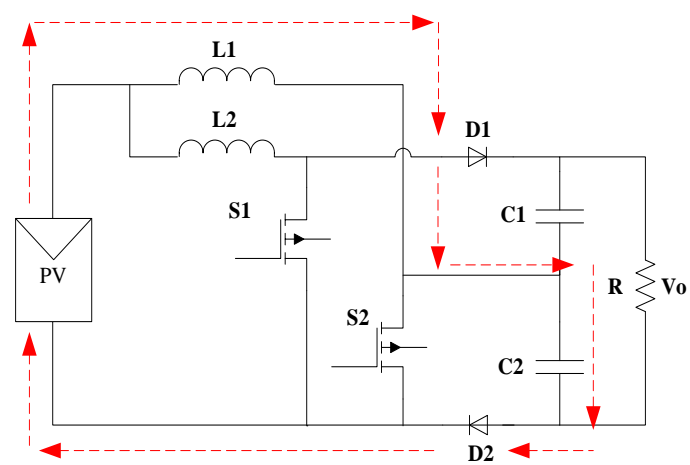

(a)

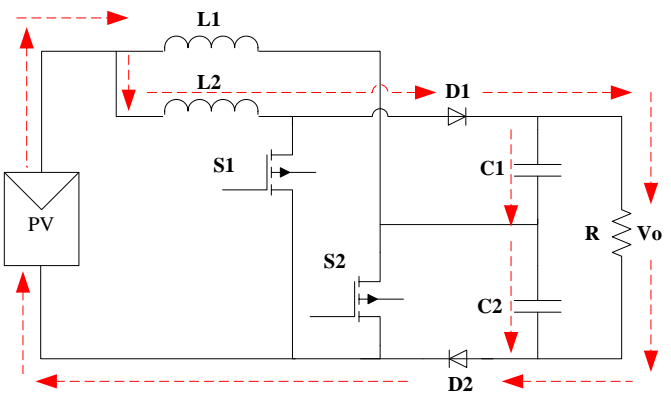

(b)

Fig.7. Mode Operation 4; (a) S2 OFF, (b) S1 OFF

\section{B. Maximum Power Point Tracker}

Photovoltaic is used to convert sun rays energy into electrical based on semiconductor principle. Whenever the intensity of sun rays increases, the cell's power output will increase too; as shown in Fig.8, photovoltaic works by using the maximum 
performance from the power output cells, stated at the maximum point. Besides the sun rays intensity and weather condition, the load factor connected to cells also affects the maximum power point.

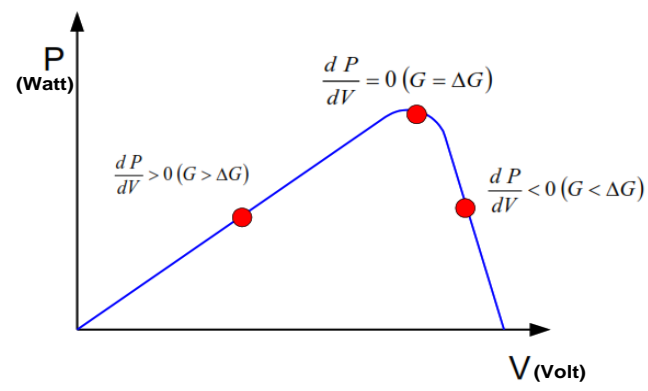

Fig.8. PV Characteristic Curve (P to V)

Perturb and observe (P\&O) method as MPPT works based on observation of the array of power output and the perturbation of the power based on increments of the array current or voltage. [20]. The reference voltage or current will be continuously decrements or increments based on the previous power sample value. $\mathrm{P} \& \mathrm{O}$ method is the simplest for its simplicity to implement with low cost [21].

$\frac{d P}{d t}$ is a change in power per minute, $\frac{d V}{d t}$ is a changing voltage per minute. Based on Fig.8. it can be seen that $\frac{d P}{d t}$ is equal $\frac{d V}{d t}$ so the equation as below could be achieved. Therefore maximum power point would be achieved.

$$
\frac{d P}{d V}=0
$$

Based on Fig.9, boost voltage doubler as a converter will be integrated with photovoltaic, which uses the MPPT algorithm to propose this research.

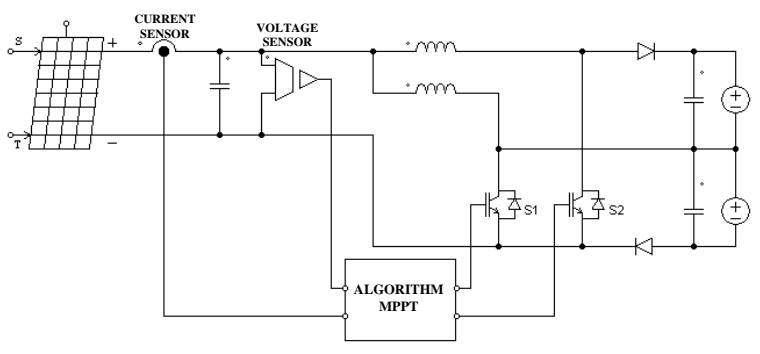

Fig.9. Topology MPPT Boost Voltage Doubler

\section{Algorithm Programming using STM32F1038CT}

The boost voltage doubler with the P\&O MPPT algorithm requires one current sensor and voltage sensor, see Fig.9. Power is generated from the multiplication of current (I) and voltage (V). Delay time used to obtain $\left(\frac{d P}{d t}\right)$ on power and voltage $\left(\frac{d V}{d t}\right)$. After getting $\left(\frac{d P}{d t}\right)$ and $\left(\frac{d V}{d t}\right)$, the equation (9) could be derived. The algorithm of $\frac{d P}{d V}$ the value should be compared with the counter to have a switching gating signal for S1 and S2. The counter is assumed to be the operator. For detailed information, the boost voltage doubler with the P\&O MPPT algorithm flowchart is shown in Fig.10. The algorithm Fig.10 is implemented using an STM32F1038CT microcontroller.

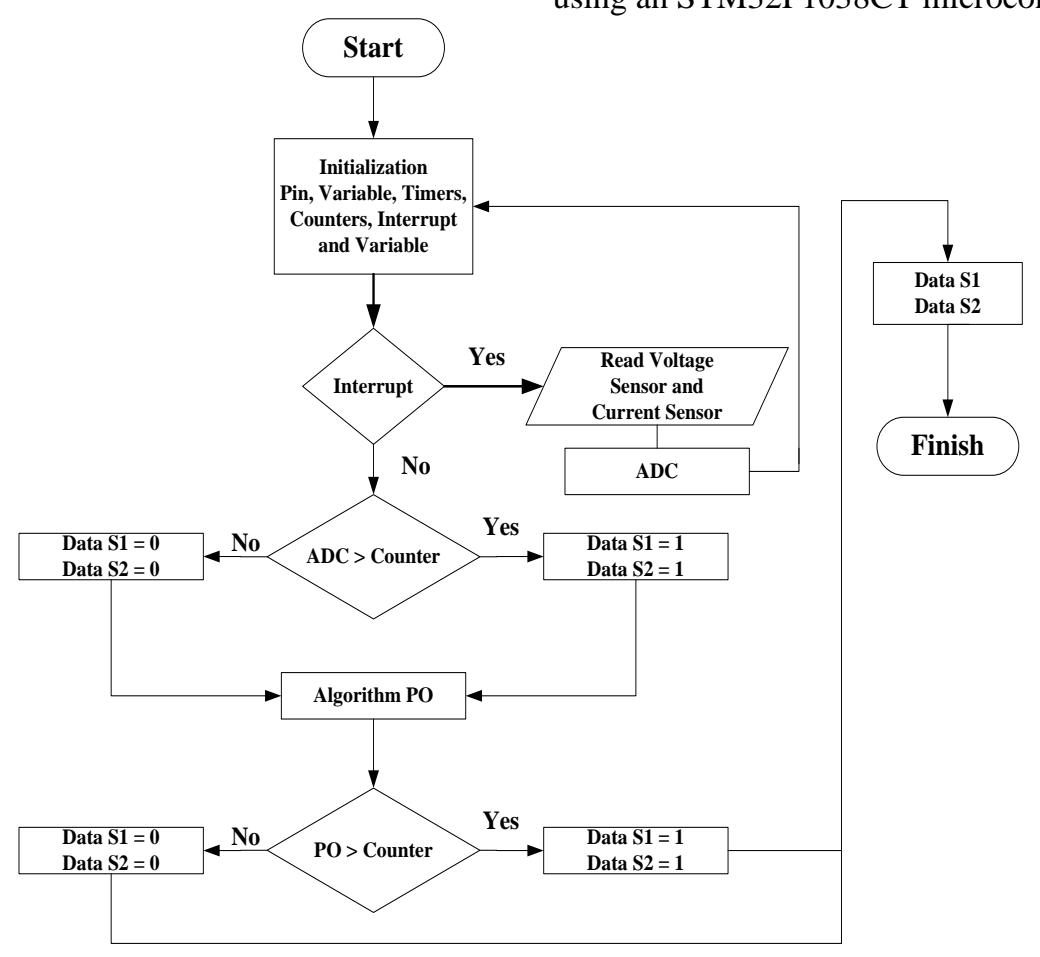

Fig.10. Flowchart Program 


\section{RESULT}

The boost voltage doubler integrated with MPPT was verified by a computation simulation using Power Simulator (PSIM) software and prototype in the laboratory test. The parameters are given in Table 1.

Table 1. Simulation Parameter

\begin{tabular}{cc}
\hline Parameters & Rating \\
\hline PV & $60 \mathrm{WP}$ \\
Inductor & Three $\mathrm{mH}$ \\
Capacitor & $220 \mathrm{uF}$ \\
Battery & $48 \mathrm{~V}$ \\
\hline
\end{tabular}

The simulation result of power output $(\mathrm{Po})$ of the proposed MPPT boost voltage doubler is always tracking maximum power $(\mathrm{Pi})$ using photovoltaic 60 WP, as shown in Fig.11. It means Po on MPPT always follows power output on PV (Pi). Moreover, the simulation result of output voltage formes the DC voltage locked at battery voltage, as shown in Fig. 12 . It means the battery was able to be charged at 48 Volt.

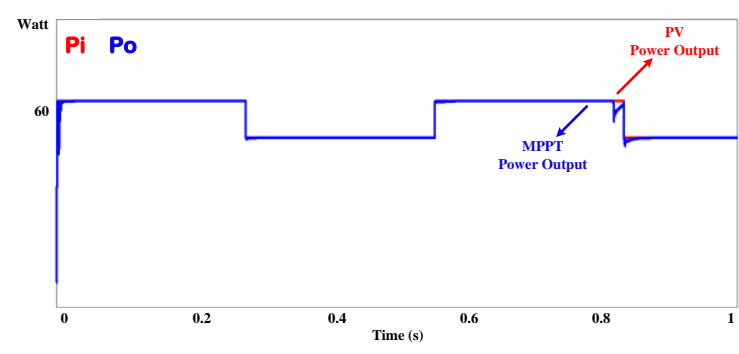

Fig.11. Output Power of PV and MPPT

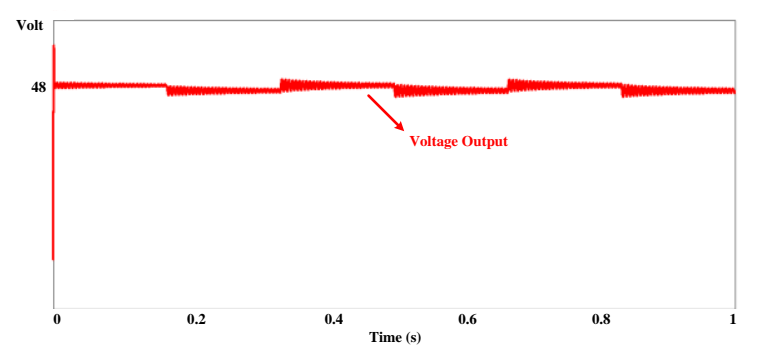

Fig.12. Output Voltage of PV and MPPT

Based on the computation simulation result and waveform shown in Fig.11, Pi gets a value of $5.4418959 \mathrm{e}+001$, and Po gets a value of 5.4303644e+001. Pi and Po's value, algorithm efficiency is $99.7 \%$, and the power converter algorithm is ideal for $100 \%$. The efficiency is derived by the equation:

$$
\eta=\frac{P o}{P i} \times 100 \%
$$

Where:

$$
\begin{aligned}
& \eta=\text { Efficiency } \\
& \text { Po }=\text { Power Output (Watt) } \\
& \text { Pi }=\text { Power Input (Watt) }
\end{aligned}
$$

Hardware implementation was done to ensure the system worked adequately using the STM32F1038CT microcontroller. MPPT boost voltage doubler, as shown in Fig.13, is an implementation that uses a battery charger.

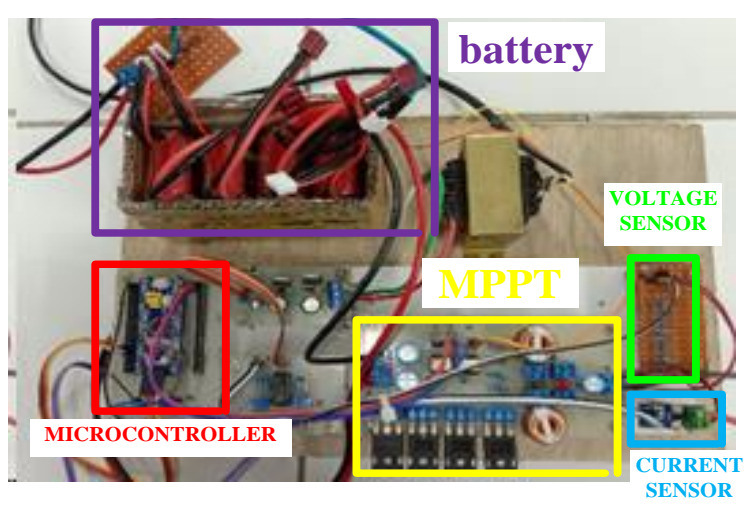

Fig.13. Implementation of MPPT Boost Voltage Doubler

On testing the boost voltage doubler hardware integrated with MPPT, the EverExceed PV 50 WP is used as a laboratory test material. The experimental result is shown in Table 2. It found converter and algorithm efficiency value. It starts from power input on $\mathrm{PV}\left(\mathrm{P}_{\mathrm{NP}}\right)$ is obtained by irradiance divided by 1000 $\mathrm{W} / \mathrm{m}^{2}$ which $1000 \mathrm{~W} / \mathrm{m}^{2}$ is assumed maximum irradiance as shown in equation (11). Then power nameplate is maximum power on $\mathrm{PV}$ in standard test condition (STC). Power nameplate is displayed 50WP based data on PV.

$P_{i n_{-} P V}=\frac{I r r}{1000^{W / \mathrm{m} 2}} \times$ Power Nameplate

Where:

$\mathrm{P}_{\text {in_PV }}=$ Power Input on PV (Watt)

Irr $\quad=$ Irradiance $\left(\mathrm{W} / \mathrm{m}^{2}\right)$

Table 2. Experimental Result

\begin{tabular}{clllllll}
\hline $\begin{array}{c}\mathrm{I}_{\text {Ir }} \\
\left(\mathrm{W} / \mathrm{m}^{2}\right)\end{array}$ & $\begin{array}{c}\mathrm{P}_{\text {in_PV }} \\
(\mathrm{W})\end{array}$ & $\begin{array}{l}\mathrm{V}_{\mathrm{pv}} \\
(\mathrm{V})\end{array}$ & $\begin{array}{c}\mathrm{I}_{\mathrm{pv}} \\
(\mathrm{A})\end{array}$ & $\begin{array}{l}\mathrm{P}_{\mathrm{o} \_\mathrm{PV}} \\
(\mathrm{W})\end{array}$ & $\begin{array}{l}\mathrm{V}_{\text {bat }} \\
(\mathrm{V})\end{array}$ & $\begin{array}{l}\mathrm{I}_{\text {bat }} \\
(\mathrm{A})\end{array}$ & $\begin{array}{l}\mathrm{P}_{\text {bat }} \\
(\mathrm{W})\end{array}$ \\
\hline $\mathbf{5 4 5}$ & 27.25 & 14.53 & 1.61 & 23.39 & 44.15 & 0.41 & 18.10 \\
$\mathbf{5 4 0}$ & 27.00 & 14.40 & 1.61 & 23.18 & 44.11 & 0.41 & 18.09 \\
$\mathbf{5 3 5}$ & 26.75 & 13.97 & 1.63 & 22.77 & 44.11 & 0.41 & 18.09 \\
$\mathbf{5 3 0}$ & 26.50 & 13.89 & 1.62 & 22.50 & 44.09 & 0.42 & 18.52
\end{tabular}




\begin{tabular}{cccccccc}
\hline $\begin{array}{c}\mathrm{I}_{\mathrm{rr}} \\
\left(\mathrm{W} / \mathrm{m}^{2}\right)\end{array}$ & $\begin{array}{c}\mathrm{P}_{\mathrm{in} \_\mathrm{PV}} \\
(\mathrm{W})\end{array}$ & $\begin{array}{c}\mathrm{V}_{\mathrm{pv}} \\
(\mathrm{V})\end{array}$ & $\begin{array}{c}\mathrm{I}_{\mathrm{pv}} \\
(\mathrm{A})\end{array}$ & $\begin{array}{c}\mathrm{P}_{\mathrm{o} \_\mathrm{PV}} \\
(\mathrm{W})\end{array}$ & $\begin{array}{c}\mathrm{V}_{\text {bat }} \\
(\mathrm{V})\end{array}$ & $\begin{array}{c}\mathrm{I}_{\text {bat }} \\
(\mathrm{A})\end{array}$ & $\begin{array}{c}\mathrm{P}_{\text {bat }} \\
(\mathrm{W})\end{array}$ \\
\hline $\mathbf{5 6 5}$ & 28.25 & 15.01 & 1.60 & 24.02 & 44.14 & 0.39 & 17.21 \\
$\mathbf{5 7 5}$ & 28.75 & 15.13 & 1.60 & 24.21 & 44.21 & 0.38 & 16.80 \\
$\mathbf{5 5 0}$ & 27.50 & 14.89 & 1.62 & 24.12 & 44.15 & 0.40 & 17.66 \\
$\mathbf{5 5 5}$ & 27.75 & 14.92 & 1.62 & 24.17 & 44.17 & 0.41 & 18.11 \\
$\mathbf{5 7 0}$ & 28.50 & 15.10 & 1.60 & 24.16 & 44.20 & 0.38 & 16.80 \\
$\mathbf{5 6 0}$ & 28.00 & 14.95 & 1.61 & 24.07 & 44.19 & 0.39 & 17.23 \\
\hline average & $\mathbf{2 7 . 6 3}$ & & & $\mathbf{2 3 . 6 6}$ & & & $\mathbf{1 7 . 6 6}$ \\
\hline efficiency & & & $\mathbf{8 5 . 6 5}$ & & $\mathbf{7 4 . 6 4}$ \\
\hline
\end{tabular}

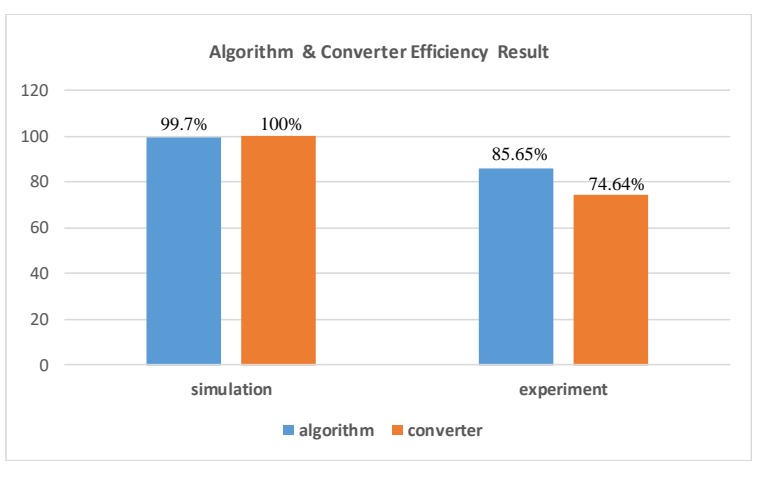

Fig.14. Efficiency Graphic

Based on experimental data as shown in Table 2, it is found that the average power input on $\mathrm{PV}$ input ( $\left.\mathrm{P}_{\text {in_PV }}\right)$ is 27.73 , power output on $\mathrm{PV}\left(\mathrm{P}_{\mathrm{o} \_\mathrm{PV}}\right)$ is 23.66 , and power output on battery $\left(\mathrm{P}_{\text {bat }}\right)$ is 17.66 . Finally, based on equation (10), the efficiency algorithm is $85.65 \%$, and the converter of boost voltage doubler efficiency is $74.64 \%$. Fig. 14 shows the comparison efficiency between simulation and hardware implementation in the laboratory test.

\section{DISCUSSION}

The principle boost voltage doubler converter combines two conventional boosts DC-DC converter. To maximize the power of $\mathrm{PV}$, the $\mathrm{P} \& \mathrm{O}$ algorithm is integrated with a boost voltage double converter. Based on the simulation result using PSIM software in ideal condition, the algorithm efficiency is $99.7 \%$, and converter efficiency is $100 \%$. Therefore, the hardware implementation efficiency of the algorithm is $85.65 \%$, and the converter efficiency is $74.64 \%$. It was caused at simulation; the irradiance was 1000 $\mathrm{W} / \mathrm{m}^{2}$. Meanwhile, the irradiance is not at the maximum point at the hardware implementation because several other factors such as wire, inductor, sun rays intensity from the photovoltaic, weather, and climate conditions are not at the maximum point and load shedding [22].

Based on the tested result, the boost voltage doubler circuit produced two times the conventional boost DC-DC converter voltage. Therefore, the boost voltage doubler that has been researched can replace the conventional boost DC-DC converter at the solar power plant application. Moreover, it is more efficient in terms of circuit, algorithm, and cost. Future research would finally implement a boost voltage doubler integrated with the MPPT algorithm to combine a five-level inverter for standalone PV application and/or grid-tie Inverter for PV application.

\section{CONCLUSION}

In the experimental laboratory results, it is proven that voltage doubler can work properly. It is shown that the output voltage $\left(\mathrm{V}_{\mathrm{bat}}\right)$ is capable of producing dual voltage from the input voltage. Thus, the voltage doubler can replace the conventional boost DC-DC converter, which needed many boosts to implement a solar power plant application. The MPPT boost voltage doubler was generated maximum power which is PV power always tracking on MPPT power with algorithm efficiency of $99.7 \%$. Moreover, the hardware implementation using STM32F1038CT microcontroller worked properly with algorithm efficiency $85.65 \%$ and converter efficiency of $74.64 \%$

\section{ACKNOWLEDGMENT}

Thanks to The Directorate General of Higher Education Ministry of National Education Indonesia (Dirjen DIKTI) 2020 Number: 010/ LL6/PG/SP2H.1/AMD/PENELITIAN/2020 for funding.

\section{REFERENCES}

[1] L. Guo, A. Brewer, and B. Speiser, "Design and implementation of a solar battery charger," in ASEE Annu. Conf. Expo. Conf. Proc., no. V, 2010, pp. 324327.

[2] F. Y. Setiono and L. H. Pratomo, "Maximum power point tracker as regulated voltage supply using ripple correlation control," in Proc. 2011 Int. Conf. Electr. Eng. Informatics, ICEEI 2011, July, 2011.

[3] S. Riyadi, "dsPIC33 Based Control for PV-Grid System with a Buck-Boost MPPT," TELKOMNIKA, vol.12, no.7, pp.5137-5143, July, 2014.

[4] S. Qin, M. Wang, T. Chen, and X. Yao, "Comparative analysis of incremental conductance and perturb-andobservation methods to implement MPPT in photovoltaic system," in 2011 Int. Conf. Electr. 
Control Eng. ICECE 2011 - Proc., 2011, pp. 57925795.

[5] C. Leu and P. Huang, "A Novel Voltage Doubler Rectifier for High Output Voltage Applications," in 2010 International Power Electronics Conference ECCE Asia -, IPEC 2010, 2010, pp. 2082-2085.

[6] I. Isakov, "Two-stage PV Converter Power Production Management During Grid Disturbances," in 2019 Int. Conf. Smart Energy Syst. Technol., 2019, pp. 1-6.

[7] Kristiawan, Iwan \& Pratomo, Leonardus, "Design and simulation full control strategy in single-phase fivelevel inverter," J. Phys.: Conf. Ser., 1444. 012032, pp.1-7, 2020.

[8] S. K. Singh and A. Haque, "Performance evaluation of MPPT using boost converters for solar photovoltaic system," in 2015 Annual IEEE India Conference (INDICON), New Delhi, India, 2015, pp.1-6, doi: 10.1109/INDICON.2015.7443516.

[9] V. B.Savakhande, M. A.Chewale, R. S.Sarwade, P. S.Chavan and A. S.Jagadale, "Coupled Inductor and Voltage Doubler Based Boost Converter for High Step-up Application," in 2018 Int. Conf. Control. Power, Commun. Comput. Technol., pp. 464-468, 2018, doi: 10.1109/ICCPCCT.2018.8574230.

[10] H. Wang, S. Dusmez and A. Khaligh, "A Novel Approach to Design EV Battery Chargers Using SEPIC PFC Stage and Optimal Operating Point Tracking Technique for LLC Converter," in 2014 IEEE Applied Power Electronics Conference and Exposition - APEC 2014, Fort Worth, TX, USA, 2014, pp. 1683-1689, doi: 10.1109/APEC.2014.6803532.

[11] Jian Fu, Bo Zhang, Dongyuan Qiu and Wenxun Xiao, "A Novel Single-Switch Cascaded DC-DC Converter of Boost and Buck- Boost Converters." in 2014 16th European Conference on Power Electronics and Applications, Lappeenranta, Finland, 2014, pp. 1-9, doi: 10.1109/EPE.2014.691072

[12] V. A. K. Prabhala, P. Fajri, V. S. P. Gouribhatla, B. P. Baddipadiga and M. Ferdowsi, "A DC-DC Converter with High Voltage Gain and Two Input Boost Stages," IEEE Transactions on Power Electronics, vol. 31, no. 6, pp. 4206-4215, June 2016, doi: 10.1109/TPEL.2015.2476377.

[13] B. Zhao, A. Abramovitz, C. Liu, Y. Yang, and Y. Huangfu, "A Family of Single-Stage, Buck-Boost
Inverters for Photovoltaic Applications for Photovoltaic Applications," Energies, MDPI, vol. 13, no.7, pp. 1-21, 2020.

[14] F. Reza Muhammad Rizki, S. Riyadi, and L. Heru Pratomo, "A SPWM Controlled Input in Dual Buck DC-DC Converter - Full Bridge for Single-Phase Five-Level Inverter," J. Phys. Conf. Ser., vol. 1444, no. 1, 2020.

[15] P. Kumari, R. K. Keshari, and S. Banerjee, "Design and implementation of photovoltaic module using multilevel inverter and boost converter," Int. Res. J. Eng. Technol., vol. 4, no. 11, pp. 1064-1068, 2017.

[16] A. S. Martins, G. C. Flores and A. T. Barden, " DC$\mathrm{DC}$ and AC-DC voltage doubler boost converter for UPS applications," in XI Brazilian Power Electronics Conference, Natal, Brazil, 2011, pp. 601-606, doi: 10.1109/COBEP.2011.6085210.

[17] M. I. Shahzad, S. Iqbal and S. Taib, "Interleaved LLC Converter with Cascaded Voltage Doubler Rectifiers for Deeply Depleted PEV Battery Charging," IEEE Transactions on Transportation Electrification, vol. 4, no. 1, pp. 89-98, March 2018, doi: 10.1109/TTE.2017.275340

[18] Y. Zhao, X. Xiang, W. Li, X. He and C. Xia, "Advanced Symmetrical Voltage Quadrupler Rectifiers for High Step-Up and High Output-Voltage Converters," IEEE Transactions on Power Electronics, vol. 28, no. 4, pp. 1622-1631, April 2013, doi: 10.1109/TPEL.2012.2211108.

[19] B. Huang, "Interleaved Voltage-Doubler Boost Converter for Power Factor Correction," in 2018 International Power Electronics Conference (IPECNiigata 2018 -ECCE Asia), Niigata, Japan, 2018, pp. 3528-3532, doi: 10.23919/IPEC.2018.8507419.

[20] H. Bounechba, K. Nebti, A. Bouzid, and H. Benalla, "Modeling and Simulation of Perturb and Observe MPPT Algorithm for PV systems," in International Conference STA'2013, 2013.

[21] P. Lei, Y. Li and J. E. Seem, "Sequential ESC-Based Global MPPT Control for Photovoltaic Array With Variable Shading," IEEE Transactions on Sustainable Energy, vol. 2, no. 3, pp. 348-358, July 2011, doi: 10.1109/TSTE.2011.2141692.

[22] F. Y. Setiono and L. H. Pratomo, "Maximum power point tracker as regulated voltage supply using ripple correlation control," in Proc. 2011 Int. Conf. Electr. Eng. Informatics, ICEEI 2011, July, 2011. 